\title{
Psicooncología
}

ISSN: 1696-7240

http://dx.doi.org/10.5209/PSIC.61443

\section{Symptoms of depression and anxiety in cancer outpatients: predictive variables}

\author{
Manuela Polidoro Lima ${ }^{1, *}$; Daiane Santos de Oliveira ${ }^{2}$; Tatiana Quarti Irigaray ${ }^{3}$
}

Recibido: 3 de junio de 2018 / Aceptado: 4 de septiembre de 2018

\begin{abstract}
Objectives: The objectives of the present study are to investigate the association among symptoms of depression and anxiety, sociodemographic variables and personality factors and also verify the predictive power of these variables in cancer outpatients. Method: The sample was composed by 220 individuals, 138 (62.7\%) women and 82 (37.3\%) men. The instruments used were: Questionnaire on sociodemographic and clinical data; NEO-FFI Personality Inventory Revised (NEO-FFI-R) and Hospital Anxiety and Depression Scale (HADS). The $t$ test and the Spearman correlation were used to verify the relation between sociodemographic and clinic variables and symptoms of anxiety and depression. A Multiple Linear Regression analysis was made to verify the predictive power of sociodemographic and clinic variables and personality factors. Results: The personality factor neuroticism was predictor of anxiety symptoms. The variable previous psychiatric history and the personality factors neuroticism and extraversion were predictors of depressive symptoms. Conclusion: Depression and anxiety symptoms are associated with some sociodemographic variables and personality factors, and these variables can be deemed risk factors for the development of these symptoms. It is important that health professionals who follow-up this population design strategies to collect this information, in order to help patients manage treatment the best way possible.
\end{abstract}

Keywords: Cancer; personality factors; anxiety; depression.

\section{[es] Síntomas de depresión y ansiedad en pacientes con cáncer: varia- bles predictivas}

Resumen: Objetivos: Los objetivos del presente estudio son investigar la asociación entre síntomas de depresión y ansiedad, variables sociodemográficas y factores de personalidad y también verificar el poder predictivo de estas variables en pacientes con cáncer. Método: La muestra estuvo compuesta por 220 individuos, $138(62,7 \%)$ mujeres y 82 (37,3\%) hombres. Los instrumentos utilizados fueron: Cuestionario sobre datos sociodemográficos y clínicos; NEO-FFI Personality Inventory Revised (NEOFFI-R) and Hospital Anxiety and Depression Scale (HADS). La prueba $t$ y la correlación de Spearman se usaron para verificar la relación entre las variables sociodemográficas y clínicas y los síntomas

1 Manuela Polidoro Lima. Postgraduate Program in Psychology at Pontifícia Universidade Católica do Rio Grande do Sul, Porto Alegre/ RS, Brazil

E-mail: manuela.lima@acad.pucrs.br

2 Daiane Santos de Oliveira. Centro Universitário Metodista IPA - Porto Alegre/RS, Brazil

E-mail: daianehausen@gmail.com

3 Tatiana Quarti Irigaray. Postgraduate Program in Psychology at Pontifícia Universidade Católica do Rio Grande do Sul, Porto Alegre/ RS, Brazil

E-mail: tatiana.irigaray@pucrs.br

* Dirección de correspondencia: Psychology Department. Avenue Ipiranga, 6681, Building 11, 9th floor. Porto Alegre / RS - Brasil CEP 90619-900. E-mail: manuela.lima@acad.pucrs.br 
de ansiedad y depresión. Se realizó un análisis de Regresión Linear Múltiple para verificar el poder predictivo de las variables sociodemográficas y clínicas y los factores de personalidad. Resultados: el factor de personalidad neuroticismo fue predictor de síntomas de ansiedad. La variable antecedentes psiquiátricos previos y los factores de personalidad neuroticismo y extraversión fueron predictores de síntomas depresivos. Conclusión: Los síntomas de depresión y ansiedad están asociados con algunas variables sociodemográficas y factores de personalidad, y estas variables pueden considerarse factores de riesgo para el desarrollo de estos síntomas. Es importante que los profesionales del campo de la salud que hacen el seguimiento de esta población proyecten estrategias para colectar esta información, a fin de ayudar a los pacientes a administrar el tratamiento de la mejor manera posible.

Palabras-clave: Cáncer; factores de personalidad; ansiedad; depresión.

Sumario. 1. Introduction 2. Method 2.1. Design 2.2. Participants 2.3. Instruments 2.4. Procedures 2.4.1. Data Collect 3. Data Analysis 4. Results 5. Discussion 6. References

Cómo citar: Lima MP, de Oliveira DS, Irigaray TQ. Symptoms of depression and anxiety in cancer outpatients: predictive variables. Psicooncología 2018;15:373-384. doi: 10.5209/PSIC.61443.

\section{Introduction}

Individuals diagnosed with cancer and undergoing any kind of cancer treatment can suffer from distress, that causes a psychological effect in their life and in their relative's life, making easier the emergence of depressive and anxiety symptoms ${ }^{(1,2)}$. These patients, comparing with general population, present 3 to 5 times higher risk of developing depressive symptoms and disorders ${ }^{(3)}$, and depressive cancer patients have higher mortality rates than those non-depressive ${ }^{(4)}$.

According to some studies, $10 \%$ to $37 \%$ of cancer patients present depressive symptomatology ${ }^{(5-9)}$. These symptoms can cause low motivation and complications during adherence treatment process. Beyond that, they can negatively affect quality of life and disease process, getting both prognostic and recovering worse and increasing death risk ${ }^{(6,10)}$.

Anxiety symptoms are, likewise, found in most cancer patients and can be caused by many reasons, like extensive treatments, recurrent hospitalizations, appointment waiting time, among others ${ }^{(11)}$. Anxiety prevalence in cancer patients can vary between $10 \%$ to $34 \%^{(5,8,12)}$.

In that way, it is possible to realize that symptoms of anxiety and depression are expected in this population, as a reaction to current condition or as an expression of cancer coping difficulties. On the other hand, it is understood that, beyond expected emotional reactions, there are some kinds of behaviors, as a response to different scenarios, that vary from one patient to another. These emotional and behavioral reactions can appear from individual personality factors that are important determinants of health behaviors ${ }^{(13)}$. According to American Psychological Association (APA) ${ }^{(14)}$, personality can be understood like a dynamic and complex integration of characteristics, shaped by wishes, values, self-concept, abilities and emotional patterns.

The concept of personality has many definitions. Besides this, there are also different theoretical models trying to explain it. One of these models is the Big Five $^{(15)}$. The Big Five theory advanced gradually, and it is currently considered one of the most up-to-date in the health sciences. Moreover, the validity of this theory in Brazilian samples has already been proven ${ }^{(16,17)}$. 
Studies indicate that life experiences and personality factors are related to remaining of anxiety and depression symptoms. Life experiences classified as negative are linked to depression permanence and relapse ${ }^{(18)}$ and to onset of anxiety disorders ${ }^{(19)}$. Other previous researchers also found relation between personality factors and symptoms of depression ${ }^{(20)}$ and anxiety ${ }^{(21-23)}$.

At the end of this brief revision, it is possible to understand that different aspects can influence individual beliefs, reactions and behavior, also interfering in disease evolution and treatment, and, finally, in the outcomes measures. Acknowledging the association between these factors can improve the developing of psychological strategies able to modify behaviors associated with prognostic improvement and better health outcomes ${ }^{(11,24)}$.

In this context, the objectives of the present study are: a) to evaluate the presence of depressive and anxiety symptoms in cancer outpatients; b) to investigate the association among symptoms of depression and anxiety and sociodemographic variables (sex, age, time since diagnosis, education level, previous psychiatric history, family psychiatric history and family cancer history) and also verify the predictive power of these variables; and c) to investigate the relation among symptoms of depression and anxiety and personality factors, and verify if these factors are predictors of symptomatologies in this population.

\section{Method}

\subsection{Design}

It is a quantitative, transversal and exploratory study.

\subsection{Participants}

The final sample was composed by 220 outpatients undergoing treatment to different oncology specialties. Based on Brazilian National Cancer Institute (Inca) ${ }^{(25)}$ estimates to 2016-2017 biennium to Porto Alegre city - including rates of cancer incidence and new cases (approximately 9,044), a sample size was calculated to define participants number, using a $5 \%$ of sample error estimation and confidence level of $95 \%$.

The participants were selected by convenience, contacted and invited to participate on the study, in waiting room of the hospital where they were being treated, while waiting to medical appointment. In total, 347 patients were invited to participate in the survey, among them, 68 refused, 41 didn't have cancer diagnostic and/or were at the hospital for first appointment, and 18 reported not having clinical conditions to collaborate with the study.

\subsection{Instruments}

The following instruments were applied, complying the order below:

a) Questionnaire on sociodemographic and clinical data: instrument utilized to collect sociodemographic and cancer data of the sample;

b) NEO-FFI Personality Inventory Revised (NEO-FFI-R) ${ }^{(26,27)}$ : it is an inventory composed by affirmative questions, to which the individual answers using one of the likert scale five alternatives described. The five domains Neuroticism, 
Extraversion, Openness to experience, Agreeableness and Conscientiousness, are represented by six facets, totalizing a group of 30 . The NEO-FFI-R version usually used in Brazil is the $\mathrm{S}$ form - answered by the own individual - constituted by 60 affirmatives. This instrument is suitable for people over 18 years of age and the Brazilian version was developed by Flores-Mendonza ${ }^{(28)}$. The authors of this inventory found a Cronbach's Alpha value that varied between 0.75 and $0.82^{(29)}$. Aluja, Garcia, Rossier \& Garcia ${ }^{(30)}$ found internal consistency value for this instrument that varied between 0.70 and 0.87 .

c) Hospital Anxiety and Depression Scale (HADS) ${ }^{(31)}$ : is a 14 itens selfevaluation scale to measure symptoms of anxiety (HADS-A) and depression (HADS-D), in two subscales, that score from 0 to 21 . The total score can vary between 0 and 42. It was used the Portuguese translated version adapted to Brazil by Botega, Bio, Zomignani, Garcia Júnior and Pereira ${ }^{(32)}$. The cut-off points adopted for both subscales followed the recommendations available on the original scale $^{(31)}$ : scores above seven (cut-off point eight) indicate the presence of anxiety and depression symptoms (doubtful cases) and scores above 11 (eleven) indicate clinical populations (definite cases).

Researches chose the cut-off point eight for cancer patients studies and found relevant results ${ }^{(1,5,33,34)}$.A meta-analysis examined HADS adequacy as a screening tool for psychiatric disorders in cancer patients, established by a structured clinical interview. The HADS-D (depression) presented values of 0.76 for sensitivity and 0.66 for specificity, and the HADS-A (anxiety) 0.66 and 0.71 respectively ${ }^{35}$. In the study of Hartung et al. ${ }^{3}$, involving cancer patients, the HADS-D presented internal consistency (Cronbach's Alpha) of 0.85 . Schellekens et al. ${ }^{(36)}$ found good internal consistency values in lung cancer patients: HADS-A 0.88 and HADS-D 0.86.

\subsection{Procedures}

\subsubsection{Data Collect}

The research project corresponding to this study was submitted and approved by a Ethical Research Committee, recognized by the National Health Council (CNS) under the number 63367316.0.0000.5336. After that, the hospital oncology department was contacted and patients were invited to participate in the study. Those participants who accepted, signed the Free and Informed Consent (TCLE) and answered, individually, the evaluation instruments suggested, in a single meeting, with an average duration of forty-five minutes.

The individuals participation was voluntary and confidentiality was assured regarding the identity of the participants. When it was necessary, the patients were referred to free Psychology services, offered by the community. The evaluation was performed by a psychologist and two trained Psychology undergraduate students.

\section{Data Analysis}

The data description was made by absolute (n) and relative (\%) frequencies for qualitative variables, and by average and standard deviation for quantitative variables. The student t-test was used to compare means of HADS considering the variables sex, previous psychiatric history, family psychiatric history and family cancer history. 
The Spearman correlations - according to data non-normal distribution, pointed by Kolmogorov-Smirnov test - was used to verify the relation between five personality factors (big five) and symptoms of anxiety and depression, and the relation between sociodemographic variables (age, time since diagnosis, education level) and symptomatologies.

After that, a Multiple Linear Regression analysis (enter method) was made to verify the predictive power of the variables and the personality factors that presented significant statist relation with the symptomatologies. The version 17 of SPSS software was used for all analyzes, considering a 5\% level of significance.

\section{Results}

The sample was composed by 220 individuals, $138(62.7 \%)$ women and $82(37.3 \%)$ men. The age mean was $54.66(\mathrm{SD}=13.30)$ years and the education level mean was $8.32(\mathrm{SD}=3.76)$ years of study. Besides that, $56.4 \%$ were married, $66.8 \%$ were not working at the moment of the study and $78.6 \%$ claimed they are religious. More information about sociodemographic and clinical data can be found in Table 1.

Table 1. Sociodemographic and clinical data of the sample $(\mathrm{N}=220)$

\begin{tabular}{llcc}
\hline Variables & & $\mathbf{N}$ & $\mathbf{\%}$ \\
\hline \multirow{2}{*}{ Sex } & Women & 138 & 62.7 \\
& Men & 82 & 37.3 \\
\hline Age (years) & Mean (SD) & $54.66(13.30)$ & \\
\hline Education (years) & Mean (SD) & $8.32(3.76)$ & \\
\hline \multirow{4}{*}{ Marital status } & Married & 124 & 56.4 \\
& Single & 49 & 22.3 \\
& Widowed & 26 & 11.8 \\
\multirow{2}{*}{ Occupational situation } & Divorced & 21 & 9.5 \\
\hline \multirow{2}{*}{ Religion } & Inactive & 147 & 66.8 \\
& Active & 53 & 24.1 \\
\hline \multirow{2}{*}{ Family cancer history } & Yes & 173 & 78.6 \\
& No & 47 & 21.4 \\
\hline \multirow{2}{*}{ Previous psychiatric history } & Yes & 152 & 70.0 \\
& No & 68 & 30.0 \\
\hline \multirow{2}{*}{ Psychiatric medication } & Yes & 46 & 21.0 \\
& No & 174 & 79.0 \\
\hline \multirow{2}{*}{ Medication category } & Yes & 48 & 21.8 \\
& No & 172 & 78.2 \\
\hline \multirow{2}{*}{ Family psychiatric history } & Antidepressant & 41 & 18.6 \\
& Anxiolytic & 05 & 2.2 \\
& Mood stabilizer & 02 & 0.9 \\
\hline
\end{tabular}




\begin{tabular}{llcc}
\hline Variables & & $\mathbf{N}$ & $\mathbf{\%}$ \\
\hline & Average (SD) & $36.21(39.8)$ & \\
Time since diagnosis (months) & 0 to 12 & 78 & 35.9 \\
& 13 to 36 & 76 & 35.0 \\
& 37 to 60 & 30 & 13.8 \\
& $>60$ & 33 & 15.0 \\
\hline \multirow{3}{*}{ Treatment } & Chemotherapy & 158 & 71.8 \\
& Surgery & 158 & 71.8 \\
& Radiotherapy & 91 & 71.4 \\
\hline \multirow{5}{*}{ Type of cancer } & Mastology & 61 & 27.7 \\
& Urology & 37 & 16.8 \\
& Lung & 37 & 16.8 \\
& Low Digestive & 23 & 10.5 \\
& High Digestive & 15 & 6.8 \\
& Hematology & 13 & 5.9 \\
& Gynecology & 10 & 4.5 \\
& Skin & 09 & 4.1 \\
& Head and neck & 07 & 3.2 \\
& Neurology (CNS) & 04 & 1.8 \\
& Orthopedic/Traumatology & 04 & 1.8 \\
\hline
\end{tabular}

Source: Research data (2017).

The HADS results indicated that 47 patients (21.4\%) scored above the established cut-off point for depression and $77(35 \%)$ above the cut-off point 7 , considered for subclinical cases, and only $23(10.5 \%)$ above cut-off point 10 , considered for clinical cases. Concerning anxiety, 77 (35\%) participants scored above cut-off point 07 (subclinical population) and 37 (16.8\%) above cut-off point 10 (clinical population). The mean score for HADS-A was $6.50(\mathrm{SD}=4.29)$ and HADS-D was 4.63 $(\mathrm{SD}=3.92)$. It is important to highlight that $48(21.8 \%)$ participants were allegedly undergoing psychiatric treatment, and 41 of these $(18.6 \%)$ declared to take antidepressant.

The scoring means of each personality factor were: neuroticism $23.06(\mathrm{SD}=7.21)$; extraversion $29.77(\mathrm{SD}=6.97)$; openness to experience $29.55(\mathrm{SD}=6.60)$; agreeableness $34.19(\mathrm{SD}=5.88)$ and conscientiousness $37.35(\mathrm{SD}=5.49)$. The correlation results between symptoms of anxiety and depression, some sociodemographic variables and personality factors are presented in Table 2 .

The symptoms of depression presented a difference between gender [ $\mathrm{t}(205)=-$ $2.81, \mathrm{p}=0.005]$, indicating that women had higher mean values $(\mathrm{M}=5.16, \mathrm{SD}=4.21)$ than men $(\mathrm{M}=3.74, \mathrm{SD}=3.20)$. Depressive symptoms were also significantly different between the participants with and without previous psychiatric history $[\mathrm{t}(55)=-3.16$, $\mathrm{p}=0.003]$ : participants with this history had a higher mean $(\mathrm{M}=6.63, \mathrm{SD}=5,13)$ than those who did not report this information $(\mathrm{M}=4.10, \mathrm{SD}=3.35)$.

Symptoms of anxiety diverged only between patients with and without previous psychiatric history $[\mathrm{t}(61)=-3.48, \mathrm{p}=0.001]$. The mean score of the patients with this history was higher $(\mathrm{M}=8.65, \mathrm{SD}=4.91)$ than the average of patients without the history $(\mathrm{M}=5.93, \mathrm{SD}=3.93)$. The variables family psychiatric history and family cancer history did not indicate difference between means regarding both symptomatologies.

The Multiple Linear Regression results are: 
Table 2. Spearman correlation analysis

\begin{tabular}{lll}
\hline Variable & Depression & \multicolumn{1}{c}{ Anxiety } \\
\hline \multicolumn{1}{c}{ Personality factors } & & \\
\hline Neuroticism & $r=.43^{* *}$ & $r=.59^{* *}$ \\
Extraversion & $r=-.33^{* *}$ & $r=-.06$ \\
Agreeableness & $r=-.15^{*}$ & $r=-.19^{* *}$ \\
Openness to experience & $r=-.18^{* *}$ & $r=.03$ \\
Conscientiousness & $r=-.24 * *$ & $r=-.14^{* *}$ \\
\hline \multicolumn{1}{c}{ Sociodemographic variables } & & \\
\hline Age & $r=.02$ & $r=-.12$ \\
Education level & $r=-.03$ & $r=.08$ \\
Diagnostic time & $r=-.09$ & $r=-.11$ \\
\hline
\end{tabular}

Note: $r=$ correlation coefficient; ${ }^{*} \mathrm{p} \leq .05 ; * * \mathrm{p} \leq .01$.

- Anxiety: the presented model explained $37.2 \%$ of the variance, and the personality factor neuroticism was the only predictor of this symptomatology. The other variables (conscientiousness, agreeableness and previous psychiatric history) didn't show predictive value, despite previous significant statistical association with symptoms of anxiety

- Depression: the model presented explained $30.4 \%$ of the variance. The presence of previous psychiatric history and the personality factors neuroticism and extraversion were shown as predictors of these symptoms. The other variables (agreeableness, conscientiousness, openness to experience and gender) did not present predictive value, even indicating statistically significant relation with symptoms of depression.

Table 3 presents the linear regression analysis detailed results, considering $\mathrm{p} \leq .05$.

Table 3. Multiple Linear Regression analysis

\begin{tabular}{|c|c|c|c|c|c|c|c|c|c|}
\hline Variables & $B$ & $S E$ & $\beta$ & $t$ & IC 95\% & $\mathbf{R}$ & $R^{2} a$ & $\mathbf{F}$ & $p$ \\
\hline \multicolumn{10}{|l|}{ Depression } \\
\hline $\begin{array}{l}\text { Previous } \\
\text { psychiatric } \\
\text { history }\end{array}$ & 1.350 & .575 & .140 & 2.346 & $.216-2.484$ & & & & \\
\hline Neuroticism & .181 & .034 & .333 & 5.254 & $.113-.248$ & & & & \\
\hline Extraversion & -.123 & .037 & -.218 & -3.328 & $-.195--.050$ & & & & \\
\hline Constant & 6.371 & 2.448 & & 2.602 & $1.545-11.197$ & .571 & .304 & 14.688 & $<.001$ \\
\hline \multicolumn{10}{|l|}{ Anxiety } \\
\hline Neuroticism & .332 & .035 & .558 & 9.351 & $.262-.402$ & & & & \\
\hline Constant & 1.507 & 2.387 & & .631 & $-3.198-6.212$ & .620 & .372 & 33.491 & $<.001$ \\
\hline
\end{tabular}

\section{Discussion}

The main goal of this study was to evaluate the presence of symptoms of depression and anxiety in cancer outpatients. The results indicate that a significant part of the sample shows both symptomatologies. Studies suggest that it is common to find 
these symptoms in cancer patients, because of the diagnostic impact and treatment consequences. Therefore, these findings agree with previous $\operatorname{research}^{(3,5-7,12)}$.

It is possible to perceive that the proportion of patients with symptoms of anxiety is bigger than that with depressive symptoms. Anxiety can be considered a patient adaptive answer to treatment adherence process or cancer screening. ${ }^{(37)}$. In this way, it can be, somehow, expected, considering the person current situation. However, in some patients, anxiety can persist in a high and uncomfortable level ${ }^{(12,38)}$.

The diagnostic time and HADS-A can help to explain this result. The majority of the sample has a maximum of three years of disease diagnostic, which can result in higher degree of uncertainty about treatment and future ${ }^{32}$. On the other hand, even those with more time since diagnosis or those called survivors - who attended the outpatient clinic only for routine annual check-up, may still experience anxiety. They may feel anxiety focuses on the fear of recurrence, which is common in survivors, possibly lasting for many years post-treatment ${ }^{(39)}$. Other potential sources of concern for these population, that may cause feelings of anxiety, are: worries about recovery from treatment in long term and worry about the impact of cancer on family, emotional and/or financial ${ }^{(40)}$.

Beyond that, when answering the HADS scale, patients were asked to take last week into consideration - before data collect. Thus, it is believed that the week before medical appointment can increase patient's anxiety, because he or she will possibly get updates about treatment, exams results or prognostic information.

The second objective of this research was to investigate the association between symptoms of depression and anxiety and sociodemographic variables and to verify if these variables have predictive value. The results pointed that previous psychiatric history is a predictor of depressive symptoms. The presence of previous psychiatric disorders can increase risk of comorbidity, like other mental disorder, for example, or even exacerbate the emotional symptoms. The symptoms relapse also can occur, especially if they were not properly treated ${ }^{(41-43)}$.

The third and last goal of this study was to investigate the relation between symptoms of depression and anxiety and personality factors, and to verify the predictive value of these factors. According to the results neuroticism and extraversion are predictors of depressive symptoms and only neuroticism is a predictor of symptoms of anxiety. The result about the predictive value of neuroticism fits with other studies results ${ }^{(21,32,44,45)}$. In a general manner, neuroticism is connected with negative life feelings, pessimist relationships and self depreciate thoughts, which make easier the emergence of feelings of sadness and ill-being ${ }^{(46)}$.

People with higher levels of neuroticism, frequently evaluate small uncomfortable stimulus as having a higher potential of negative impact, and these threat perceptions can develop affective and cognitive depressive symptoms ${ }^{(47)}$. Many times, these individuals present more demanding and unrealistic expectations about themselves, which can increase anxiety levels, impairing the coping of stress situations ${ }^{(48,49)}$. One of the explanatory hypotheses is that patients symptoms of anxiety, in this study, may have been triggered by this process, which implies both neuroticism influence and coping of adverse situations, like cancer disease, for example.

Another predictor factor of depression symptoms is extraversion that, in this research, decrease the risk of symptoms. These results corroborate other studies found in the literature ${ }^{(50-53)}$. A recent study, developed with brain tumor patients, also found a high correlation between depressive symptoms and low levels of extraversion ${ }^{(54)}$. The 
extroversion personality factor is, in fact, linked to expansion behaviors, social stimulation, more optimistic relationships, and to a more assertive attitude towards people ${ }^{(42,55)}$. These characteristics have already pointed an inverse and significant association with a lower ability to tolerate frustrations, emotional instability, depressed mood, guilt, fatigue and loss of interest ${ }^{(56)}$, features and symptoms found in individuals with high levels of neuroticism.

It is possible to conclude that the prevalence of anxiety and depression symptoms in cancer outpatients is high, and these symptomatologies are associated with some sociodemographic variables and personality factors, like neuroticism and extraversion. Therefore, these variables can be deemed risk factors for the development of these symptoms. The association between some personality factors with anxiety and depression, as reported in this article, seems to be already established in the literature. However, most of the mentioned studies were developed with nonclinical populations, unlike the present study. For that matter, it is believed that this association should also be considered mostly in cases of individuals with cancer diagnostic, in face of the damage caused by symptoms of anxiety and depression to the treatment and rehabilitation of cancer patients.

It is important that health professionals who treat and follow-up this population design strategies to collect this information, in order to help patients manage to treatment the best way possible. Finally, some limitations of the study need to be mentioned. The sample evaluated is originated from only one health service establishments, which can difficult the results generalization. Besides that, the patient's cancer staging and the outcome of relative's disease of those participants with family cancer history were not assessed, and these variables could help grounding the prevalence of symptoms of anxiety and depression in this sample. Future research should be developed with different samples, coming from different health care settings, and including the evaluation of these clinical aspects of disease, which can also influence the symptoms presence and/or magnitude.

\section{References}

1. Ristevska-Dimitrovska G, Stefanovski P, Smichkoska S, Raleva M, Dejanova B. Depression and resilience in breast cancer patients. Maced J Med Sci 2015;3:661-5. doi: 10.3889/oamjms.2015.119

2. Salvo N, Zeng L, Zhang L, Leung M, Khan L, Presutti R, et al. Frequency of reporting and predictive factors for anxiety and depression in patients with advanced cancer. Clin Oncol (R Coll Radiol) 2012;24:139-48. doi: 10.1016/j.clon.2011.05.003

3. Hartung TJ, Brahler E, Faller H, Harter M, Hinz A, Johansen C, et al. The risk of being depressed is significantly higher in cancer patients than in the general population: prevalence and severity of depressive symptoms across major cancer types. Eur J Cancer 2017;72:46-53. doi: 10.1016/j.ejca.2016.11.017

4. Suppli NP, Johansen C, Kessing LV, Toender A, Kroman N, Ewertz M, et al. Survival after early-stage breast cancer of women previously treated for depression: a nationwide Danish cohort study. J Clin Oncol 2017;35:334-42. doi:10.1200/JCO.2016.68.8358

5. Arrieta O, Ângulo LP, Nunez-Valencia C, Dorantes-Gallareta Y, Macedo EO, MartínezLópez D, et al. Association of depression and anxiety on quality of life, treatment adherence, and prognosis in patients with advanced non-small cell lung cancer. Ann Surg Oncol 2013; 20:1941-8. doi: 10.1245/s10434-012-2793-5 
6. de Souza BF, de Moraes JA, Inocenti A, dos Santos MA, Silva AEBC, Miasso AI. Women with breast cancer taking chemotherapy: depression symptoms and treatment adherence. Rev Lat Am Enfermagem 2014;22:866-73. doi: 10.1590/0104-1169.3564.2491

7. Muzzatti B, Mella S, Bomben F, Flaiban C, Gipponi K, Piccinin M, et al. Intensity and prevalence of depressive states in cancer patients: a large sample descriptive study. Eur $\mathrm{J}$ Cancer Care. 2016;00:1-5. doi: 10.1111/ecc.12542

8. Polidoro Lima M, Osório FL. Indicators of psychiatric disorders in different oncology specialties: a prevalence study. J Oncol 2014;2014:350262. doi: 10.1155/2014/350262

9. Yusof S, Zakaria FN, Hashim NK, Dasiman R. Depressive symptoms among cancer patients undergoing chemotherapy. Procedia Soc Behav Sci 2016; 234:185-92. doi: 10.1016/j.sbspro.2016.10.233

10. Reyes-Gibby CC, Anderson KO, Morrow PK, Shete S, Hassan S. Depressive symptoms and health-related quality of life in breast cancer survivors. J Womens Health (Larchmt) 2012;21:311-8. doi: 10.1089/jwh.2011.2852

11. Kendler KS, Gardner CO. A longitudinal etiologic model for symptoms of anxiety and depression in women. Psychol Med 2011;41:2035-45. doi:10.1017/S0033291711000225

12. Mitchell AJ, Chan M, Bhatti H, Halton M, Grassi L, Johansen C, et al. Prevalence of depression, anxiety, and adjustment disorder in oncological, hematological, and palliative-care settings: a meta-analysis of 94 interview-based studies. Lancet Oncol 2011;12:160e74. doi: 10.1016/S1470-2045(11)70002-X

13. Bogg T, Roberts BW. The case for conscientiousness: evidence and implications for a personality trait marker of health and longevity. Ann Behav Med 2013;45:278-88. doi: 10.1007/s12160-012-9454-6

14. American Psychological Association. Dicionário de Psicologia. Porto Alegre: Artmed, 2010.

15. Costa Jr. PT, McCrae RR. The NEO Personality Inventory Manual. Odessa: Psychological Addessment Resources, 1985.

16. McCrae RR, Allik J. The Five Factor Model of Personality across cultures. New York: Kuwler Academic/Plenum Publisher, 2002.

17. Silva IB, Nakano TC. Modelo dos cinco grandes fatores da personalidade: análise de pesquisa. Aval Psicol 2011;10:51-62.

18. Paykel ES. Life events and affective disorders. Acta Psychiatr Scand 2003;108:61-6. doi: 10.1034/j.1600-0447.108.s418.13.x

19. Kendler KS, Hettema JM, Butera F, Gardner CO, Prescott CA. Life event dimensions of loss, humiliation, entrapment, and danger in the prediction of onsets of major depression and generalized anxiety. Arch Gen Psychiatry 2003;60:789-96. doi: 10.1001/ archpsyc.60.8.789

20. Drieling T, van Calker D, Hecht H. Stress, personality and depressive symptoms in a 6.5 year follow-up of subjects at familial risk for affective disorders and controls. J Affect Disord 2006;91:195-203. doi:10.1016/j.jad.2006.01.004

21. Kotov R, Gamez W, Schmidt F, Watson D. Linking 'big' personality traits to anxiety, depressive, and substance use disorders: a meta-analysis. Psychol Bull 2010; 136:768821. doi: 10.1037/a0020327

22. Vassend O, Skrondal A. The NEO personality inventory revised (NEO-PI-R): exploring the measurement structure and variants of the five-factor model. Pers Individ Dif 2011;50:1300-4. doi: 10.1016/j.paid.2011.03.002

23. Vreeke LJ, Muris P. Relations between behavioral inhibition, big five personality factors, and anxiety disorder symptoms in non-clinical and clinically anxious children. Child Psychiatry Hum Dev 2012;43:884-94. doi: 10.1007/s10578-012-0302-5 
24. Baptista MN, dos Santos KM, Dias RR. Auto-eficácia, lócus de controle e depressão em mulheres com câncer de mama. Psicol Argum, Curitiba 2006;24:27-36. doi: 10.7213/rpa. v24i44.19909

25. Instituto Nacional do Câncer (Inca) (2016). Brasil. Estimativa 2016: incidência de câncer no Brasil. [Internet] Rio de Janeiro: Ministério da Saúde. Retrieved from:ggghttp://www. inca.gov.br/estimativa/2016/tabelaestados.asp?UF=RS.

26. Costa Jr. PT, McCrae RR. The NEO-PI/NEO-FFI manual supplement. Odessa: Psychological Assessment Resources, 1989.

27. Costa Jr. PT, McCrae RR. Revised NEO Personality Inventory (NEO-PI-R) and NEO FiveFactor Inventory (NEO-FFI) professional manual. Odessa: Psychological Assessment Resources, 1992.

28. Flores-Mendonza CE. Inventário de personalidade NEO-Revisado. Manual técnico. São Paulo: Vetor Editora, 2007.

29. McCrae RR, Costa P. A contemplated revision of the NEO Five-Factor Inventory. Pers Individ Dif 2004;36:587-96. doi:10.1016/S0191-8869(03)00118-1

30. Aluja A, Garcia O, Rossier J, Garcia L. Comparison of the NEO-FFI, NEO-FFI-R and an alternative short version of the NEO-PI-R (NEO-60) in Swiss and Spanish samples. Pers Individ Dif 2005;38:591-604. doi:10.1016/j.paid.2004.05.014

31. Zigmond AS, Snaith RP. The Hospital Anxiety and Depression Scale. Acta Psychiatr Scand 1983;67:361-70. doi: 10.1111/j.1600-0447.1983.tb09716.x

32. Botega NJ, Bio MR, Zomignani MA, Garcia Júnior C, Pereira WA. Transtornos do humor em enfermaria de clínica médica e validação de escala de medida (HAD) de ansiedade e depressão. Rev Saúde Pública 1995;29:355-63. doi:10.1590/S0034-89101995000500004

33. Shimizu K, Nakaya N, Saito-Nakaya K, Akechi T, Ogawa A, Fujisawa D, et al. Personality traits and coping styles explain anxiety in lung cancer patients to a greater extent than other factors. Jpn J Clin Oncol 2015;45:456-63. doi: 10.1093/jjco/hyv024.

34. Srivastava V, Ansari MA, Kumar A, Shah AG, Meena RK, Sevach P, et al. Study of anxiety and depression among breast cancer patients from North India. J Clin Psychiatry 2016;2:1-7. doi:10.21767/2471-9854.100017

35. Mitchell AJ, Meader N, Symonds P. Diagnostic validity of the Hospital Anxiety and Depression Scale (HADS) in cancer and palliative settings: a meta-analysis. J Affect Disord 2010;126:335-48. doi: 10.1016/j.jad.2010.01.067

36 Schellekens MPJ, van den Hurk DGM, Prins JB, Molema J, van der Drift MA, Speckens AEM. The suitability of the Hospital Anxiety and Depression Scale, Distress Thermometer and other instruments to screen for psychiatric disorders in both lung cancer patients and their partners. J Affect Disord 2016;203:176-83. doi: 10.1016/j.jad.2016.05.044

37. Kudadjie-Gyamfi E, Consedine N, Magai C, Gillespie M, Pierre-Louis J. Breast selfexamination practices among women from six ethnic groups and the influence of cancer worry. Breast Cancer Res Treat 2005;92:35-45. doi:10.1007/s10549-005-0154-9

38. Brintzenhofe-Szoc KM, Levin TT, Li Y, Kissane DW, Zabora JR. Mixed anxiety/ depression symptoms in a large cancer cohort: Prevalence by cancer type. Psychosomatics 2009;50:383-91. doi: 10.1176/appi.psy.50.4.383

39. Lee-Jones C, Humphris G, Dixon R, Hatcher M. Fear of cancer recurrence: a literature review and proposed cognitive formulation to explain exacerbation of recurrence fears. Psychooncology. 1997;6:95-105. doi: 10.1002/(SICI)1099-1611(199706)6:2<95::AIDPON250>3.0.CO;2-B

40. Moye J, Wachen JS, Mulligan EA, Doherty K, Naik AD. Assessing multidimensional worry in cancer survivors. Psychooncology 2014;23:237-40. doi: 10.1002/pon.3381. 
41. Ferriolli SHT, Marturano EM, Puntel LP. Contexto familiar e problemas de saúde mental infantil no Programa Saúde da Família. Rev. Saúde Pública 2007;41:251-9. doi: 10.1590/ S0034-89102006005000017

42. Goebel S, Von Harscher M, Mehdorn HM. Comorbid mental disorders and psychosocial distress in patients with brain tumors and their spouses in the early treatment phase. Support Care Cancer 2011;19:1797-805. doi: 10.1007/s00520-010-1021-8

43. Jiménez-Castro L, Raventós-Vorst H, Escamilla M. Esquizofrenia y trastorno en el consumo de sustancias: prevalencia y características sociodemográficas en la población latina. Actas Esp Psiquiatr 2011;39:123-30.

44. Koorevaar AM, Comijs HC, Dhondt AD, van Marwijk HW, van der Mast RC, Naarding P. Big five personality and depression diagnosis, severity and age of onset in older adults. J Affect Disord 2013;151:178-85. doi: 10.1016/j.jad.2013.05.075

45. Wang Y, Yao L, Liu L, Yang X, Wu H, Wang J, et al. The mediating role of self-efficacy in the relationship between Big five personality and depressive symptoms among Chinese unemployed population: a cross-sectional study. BMC Psychiatry 2014;14:61. doi:10.1186/1471-244X-14-61

46. Thomson W. Depression, Neuroticism, and the discrepancy between actual and ideal selfperception. Pers Individ Dif 2016; 88:219-24. doi:10.1016/j.paid.2015.09.003

47. Mak AS, Blewitt K, Heaven PCL. Gender and personality influences in adolescent threat and challenge appraisals and depressive symptoms. Pers Individ Dif 2004;36: 1483-96. doi:10.1016/S0191-8869(03)00243-5

48. Enns MW, Cox BJ, Clara IP. Perfectionism and neuroticism: a longitudinal study of specific vulnerability and diathesis-stress models. Cognit Ther Res 2005;29:463-78. doi:10.1007/s10608-005-2843-04

49. Laurenti HJ, Bruch MA, Haase RF. Social anxiety and socially prescribed perfectionism: unique and interactive relationships with maladaptive appraisal of interpersonal situations. Pers Individ Dif 2008;45:55-61. doi:10.1016/j.paid.2008.02.018

50. Chien LL, Ko HC, Wu JYW. The five-factor model of personality and depressive symptoms: One-year follow-up. Pers Individ Dif 2007;43:1013-23. doi:10.1016/j.paid.2007.02.022

51. Naragon-Gainey K, Watson D. Consensually defined facets of personality as prospective predictors of change in depression symptoms. Assessment 2014;21:387-403. doi: 10.1177/1073191114528030

52. Renner F, Penninx BWJH, Peeters F, Cuijpers P, Huibers MJH. Two-year stability and change of neuroticism and extraversion in treated and untreated persons with depression: Findings from the Netherlands Study of Depression and Anxiety (NESDA). J Affect Disord 2013;150:201-8. doi: 10.1016/j.jad.2013.03.022.

53. Watson D, Naragon-Gainey K. Personality, emotions, and the emotional disorders. Clin Psychol Sci 2014;2:422-42. doi:10.1177/2167702614536162

54. Bunevicius AJ. Personality traits, patient-centered health status and prognosis of brain tumor patients. J Neurooncol 2018;137:593-600. doi: 10.1007/s11060-018-2751-6.

55. Costa Jr. PT, McCrae RR. NEO PI-R: Inventário de Personalidade Neo revisado; e Inventário de cinco fatores Neo revisado. São Paulo: Vetor, 2010.

56. Watson D, Stasik SM, Ellickson-Larew S, Stanton K. Extraversion and psychopathology: A facet-level analysis. J Abnorm Psychol 2015;124:432-46. doi: 10.1037/abn0000051. 